\title{
What Drives People Visit Restaurants During COVID-19 Pandemic? Findings in Indonesia
}

\author{
Dewi Agustin Pratama SARI ${ }^{\star *}$, Dwi Kismayanti RESPATI², Ayatulloh Michael MUSYAFFI ${ }^{3}$ \\ ${ }^{123}$ Faculty Economic, Universitas Negeri Jakarta, Indonesia, Rawamangun, Kec. Pulo Gadung, Kota Jakarta Timur, Daerah \\ Khusus Ibukota Jakarta 13220 \\ Email: dewiagustin@unj.ac.id¹, dwikisrespati@unj.ac.id², musyaffi@unj.ac.id³ \\ ${ }^{*}$ Corresponding Author
}

\begin{abstract}
Received: 18.11.2021 $\quad$ Accepted: 05.12.2021 $\quad$ Published: 02.02.2022 $\quad$ DOI: 10.47750/QAS/23.186.09
\end{abstract}
\begin{abstract}
The current COVID-19 pandemic has had a wide impact on the global economic sector. Restaurants are one of the sectors affected by the regulation of distance restrictions during the COVID-19 pandemic. Therefore, this study looks at what factors can encourage people to visit restaurants when government regulations have allowed consumers to make food purchases offline. This study looks at five factors; disease denial, perceived safety, perceived fair price, sociability and affect regulation. The sample in this study were 133 respondents. Furthermore, the data is processed using SEM-PLS using SmartPLS 3.0. The study results indicate that perceived safety, sociability and affect regulation have a significant positive impact on a person's intention to visit a restaurant. This research contributes to both improving the theory of a person's intention to visit a restaurant during the Covid-19 pandemic and helping restaurant service providers decide on an effective strategy in encouraging someone to have the intention to visit a restaurant.
\end{abstract}

Keyword: Affect Regulation, COVID-19 Pandemic, Perceived Safety, Sociability, Visit Restaurant

\section{Introduction}

The current and ongoing COVID-19 pandemic has had a wide impact on global economic sectors, where almost every business sector worldwide has been negatively affected (Keni \& Wilson, 2021). The restaurant industry is one of the most affected businesses during the COVID-19 outbreak. Customers will consider choosing whether to eat in a restaurant or not because of this epidemic (Yost \& Cheng, 2021).

The restaurant business sector plays an important role in the economy of a country. However, many small and medium-sized restaurants will fail during the first four years of their activities, so a strategy is needed to maintain their business finances beyond five years (Madeira et al., 2021). In this Covid-19 pandemic situation, restaurant management needs to make a strategy to survive. Researchers are now eager to find ways to help restaurants overcome adversity and recover in and after the COVID-19 era, particularly regarding "post-COVID-19" customer management (Yost \& Cheng, 2021).

In order to prevent the spread of the Covid-19 virus, the Indonesian government has made restrictions on public social interaction. One of them is the restriction of restaurant operating hours and a ban on eating on the spot. The "new normal" era makes people change their behaviour and lifestyle. The concern of people gathering in one place is one of the considerations for eating at a restaurant. Keeping a distance is one of the requirements of the community when in public places. When people think that going outside to public places (such as restaurants) will increase the risk of being infected with the virus, it is less likely that people or consumers will immediately visit the restaurant no matter how strong their desire to visit the restaurant is (Keni \& Wilson, 2021).
Several previous studies have found factors that motivate people or consumers to eat in restaurants, especially during this pandemic. Dedeoğlu \& Boğan's (2021) research found that two motivations, namely, socialization, positively impact people's intention to visit high-end restaurants in Istanbul, Turkey. With the reopening of restaurants, people feel they can meet and spend time with people in their social environment. When the government tries to control social life, there are a series of measures and regulations to prevent the spread of the virus (Dedeoğlu \& Boğan, 2021). The regulation brings consumers confidence that their safety will be maintained when in public places, especially restaurants.

Research conducted by Hakim et al., 2021) on Brazilian society shows that consumer confidence in restaurants and brands, food prices, solidarity with restaurants, disease denial, and trust in health surveillance affect intentions to visit restaurants during the COVID-19 pandemic.

In addition, Keni \& Wilson's, 2021 research on fast food restaurants in Indonesia, found that perceived risk factors significantly affect consumer intentions to visit fast-food restaurants, where consumers have a tendency not to visit restaurants if there is a large risk associated with the visit. However, the restaurant also found that the restaurant's sales promotion also motivates consumers to visit the restaurant. Consumers consider that the risk of a pandemic is still low, so many visit restaurants to enjoy the promotions provided by the restaurant.

This study aims to find out more broadly about what factors motivate consumers to visit restaurants. This study will examine how disease denial, perceived safety and fair price, and sociability \& affect regulation motivate consumers to visit restaurants during the Covid-19 pandemic. 


\section{Literature Review}

In a business with a service category, a direct meeting between service providers and consumers is one of the processes of consuming a product. This is what drives COVID19 to greatly influence this sector, one of which is restaurants (Hakim et al., 2021). The study explains that there was a 100\% decrease in consumer reservations at restaurants in different countries (OpenTable, 2020).

\subsection{Disease Denial}

The COVID-19 pandemic is a new outbreak, where various researchers in the health sector are still exploring information about this outbreak. Various countries every day try to continue to provide information about the development of the COVID-19 virus. Various reports, both accountable and just leading opinions, can be easily found on various social media (Torales et al., 2020). The existence of various news, which sometimes leads to issues, makes uncertainty continue to increase. However, appeals such as self-isolation, social distancing and the use of masks are known to increase a person's fear (Hakim et al., 2021). However, the presence of COVID-19 increases mental health problems (Torales et al., 2020). The feeling of a high risk of COVID-19 increases a person's fear. However, it turns out that there are also people with the opposite category of fear of COVID-19. There are groups of people with indifferent or disapproving reactions to this information about COVID-19. Denial itself is defined as a rejection of various information that can be accounted for (Denial, 2020). Therefore, someone who is in denial about an event, then that person tends to reject all the truth about the information. In the case of a pandemic, a person in the denial category can be interpreted as not believing in COVID-19, so in this study, it is suspected that the existence of denial has a significant positive effect on people intention of visiting restaurants.

$\mathrm{H} 1$ : Disease denial is positively related to the intention to visit restaurants during the pandemic

\subsection{Perceived Safety and Fair Price}

Brands have an important role in differentiating a product in the market, both goods and services (Hakim et al., 2021). When marketers develop a product, both goods and services, they will connect with their consumers. Of course, this aims to follow what consumers need so that they will become products that cannot be replaced with other brands (Wheeler, 2017). This is supported by other studies which explain that a good presentation of satisfaction, good communication, value, production and good quality standards can increase consumer comfort and have positive associations with the brand (Berry, 2000; Ozdemir et al., 2020). Positive associations with brands will lead to consumer confidence in the product. Furthermore, this built-up trust will create a more comfortable feeling and reduce consumer's thoughts on product risks. Trust in the brand, and the perception of the right price can also increase consumer confidence in the product. In this study, it is assumed that the perception of safety and knowing the brand well will significantly positively affect consumers' intentions to visit restaurants.

$\mathrm{H} 2$ : Perceived safety is positively related to the intention to visit restaurants during the pandemic.

H3: The perceived fair price is positively related to the intention to visit restaurants during the pandemic.

\subsection{Sociability \& Affect regulation}

Sociability is one of the motivations for a person in eating together (Renner et al., 2012). Another understanding of sociability is a social influence in a person's decision about the food to be consumed. The existence of social impacts greatly influences food consumption (Dedeoğlu \& Boğan, 2021). People who have sociability in the decision process to buy the food they consume will think that social image is very important. Furthermore, food consumption can also be influenced by affect regulation. Affect regulation describes people's tendency that food influences responding to their negative emotions. Therefore, in this study, it is assumed that the existence of sociability and also affect regulation will have a significant positive effect on a person's intention to visit a restaurant.

$\mathrm{H} 4$ : Sociability positively affects visit intention to upscale restaurants

H5: Affect regulation positively affects visit intention to upscale restaurants

\section{Methodology}

The research hypothesis was conducted to obtain a provisional estimate of the development of the research model. So to ensure that the hypothesis that has been built has resulted following the data and facts in the field, it requires the right method. This research was built based on scientific considerations. Each construct item in this study was made based on previous research. There are five constructs used in this study. Disease denial has 3 question items (Costa, 2020), perceived safety has three items. The questionnaire was compiled based on an adaptation of the research of Hakim et al. (2020) and the fair price variable, which has 3 question items adopted from the research by Hakim et al. (2020). Furthermore, the construct of sociability and affect regulation adapted from research (Dedeoğlu \& Boğan, 2021) also has three questions. Lastly, the intention to visit construct has 3 question items adapted from research $\mathrm{H}$. Each of the question items has five answer choices. Using a Likert scale, namely strongly agree, agree, neutral, disagree, and strongly disagree. Using the 5point Likert scale is because it was recommended by previous researchers (Dawes, 2008). After all, it can produce an average score that is slightly higher than the 10-point scale. After that, the questionnaires were randomly distributed online to users who used the online food delivery service facility. The recommended number of samples to test the PLS-SEM model is $10-150$ samples (Rezaei, 2015). The statement is following the results that the researchers, namely 133 respondents, collected. After that, the data obtained were analyzed using SEM-PLS with the help of SmartPLS 3.0, starting from validity and reliability testing, structural model testing, and hypothesis testing.

\section{Result}

The discussion section of the research results contains the analysis based on statistical results. The data is processed using smart pls 3.0. There are three stages carried out, namely measurement model, structural model and hypothesis testing

\subsection{Measurement model}

This section describes the analysis of the measurement model results. A measurement model is used to ensure that the data obtained is valid and reliable. The analysis used outer loading (> 0.7), Cronbach's alpha (CA) (CA value> 0.7), Composite Reliability (CR) (CR>0.7), and Average Variance Extracted (AVE) (AVE> 0.5) (Hair et al. al., 2018). Table 1 shows the value of the validity and reliability of each construct. Based on the table, the outer loading value for all items in this study is worth more than 0.7 , exceeding the recommended value. Thus, 


\section{GENERAL MANAGEMENT}

further analysis can be made on CA, CR and AVE. CA and CR values in table 1 below show a number that exceeds 0.7 with the largest value in the sociability construct. Then the AVE value also shows results that exceed the recommended number (0.5). So it can be concluded that all constructs and items in this study are valid and reliable.

\begin{tabular}{|l|l|l|l|l|}
\hline & $\begin{array}{l}\text { Outer } \\
\text { loading }\end{array}$ & $\begin{array}{l}\text { Cronbach's } \\
\text { Alpha }\end{array}$ & $\begin{array}{l}\text { Composite } \\
\text { Reliability }\end{array}$ & $\begin{array}{l}\text { Average Variance } \\
\text { Extracted (AVE) }\end{array}$ \\
\hline Affect regulation (AR) & & 0.8060 & 0.8846 & 0.7193 \\
\hline AR1 & 0.8757 & & & \\
\hline AR2 & 0.8777 & & & \\
\hline AR3 & 0.7877 & & & \\
\hline Disease Denial (DD) & & 0.7674 & 0.8594 & 0.6711 \\
\hline DD1 & 0.8518 & & & \\
\hline DD2 & 0.7762 & & & \\
\hline DD3 & 0.8278 & & & 0.6533 \\
\hline Fair Price (FP) & & 0.7359 & 0.8496 & \\
\hline FP1 & 0.8130 & & & \\
\hline FP2 & 0.8199 & & & \\
\hline FP3 & 0.7917 & & & \\
\hline Intention to Visit (IV) & & 0.7642 & 0.8631 & \\
\hline IV1 & 0.8020 & & & \\
\hline IV2 & 0.7833 & & & \\
\hline IV3 & 0.8820 & & & \\
\hline Perceived Safety (PS) & & 0.7423 & 0.8506 & 0.6550 \\
\hline PS1 & 0.7804 & & & \\
\hline PS2 & 0.8237 & & & \\
\hline PS3 & 0.8231 & & & \\
\hline Sociability (SOC) & & 0.9406 & 0.9618 & 0.8936 \\
\hline SOC1 & 0.9428 & & & \\
\hline SOC2 & 0.9543 & & & \\
\hline SOC3 & 0.9387 & & & \\
\hline
\end{tabular}

Table 1: validity and reliability

\begin{tabular}{|l|l|l|l|l|l|l|}
\hline & $\begin{array}{l}\text { Affect } \\
\text { regulation (AR) }\end{array}$ & $\begin{array}{l}\text { Disease } \\
\text { Denial (DD) }\end{array}$ & Fair Price (FP) & $\begin{array}{l}\text { Intention } \\
\text { to Visit (IV) }\end{array}$ & $\begin{array}{l}\text { Perceived } \\
\text { Safety (PS) }\end{array}$ & $\begin{array}{l}\text { Sociability } \\
\text { (SOC) }\end{array}$ \\
\hline AR1 & 0.8757 & 0.2892 & 0.3848 & 0.3824 & 0.3523 & 0.4381 \\
\hline AR2 & 0.8777 & 0.2705 & 0.3737 & 0.3444 & 0.3292 & 0.3897 \\
\hline AR3 & 0.7877 & 0.5488 & 0.6265 & 0.4590 & 0.6465 & 0.4326 \\
\hline DD1 & 0.3968 & 0.8518 & 0.4410 & 0.3805 & 0.4326 & 0.2964 \\
\hline DD2 & 0.3452 & 0.7762 & 0.4866 & 0.2160 & 0.5286 & 0.2519 \\
\hline DD3 & 0.3732 & 0.8278 & 0.4904 & 0.2543 & 0.5345 & 0.2754 \\
\hline FP1 & 0.3954 & 0.3581 & 0.8130 & 0.3922 & 0.4871 & 0.4617 \\
\hline FP2 & 0.5195 & 0.5383 & 0.8199 & 0.3865 & 0.5050 & 0.3607 \\
\hline FP3 & 0.4552 & 0.4837 & 0.7917 & 0.3216 & 0.5784 & 0.4658 \\
\hline IV1 & 0.3414 & 0.2710 & 0.2928 & 0.8020 & 0.3057 & 0.3782 \\
\hline IV2 & 0.3776 & 0.3206 & 0.4488 & 0.7833 & 0.5434 & 0.3629 \\
\hline IV3 & 0.4471 & 0.3004 & 0.3616 & 0.8820 & 0.4385 & 0.3424 \\
\hline PS1 & 0.4584 & 0.5613 & 0.5406 & 0.3769 & 0.7804 & 0.2943 \\
\hline PS2 & 0.5234 & 0.4851 & 0.5741 & 0.3756 & 0.8237 & 0.4198 \\
\hline PS3 & 0.3719 & 0.4143 & 0.4687 & 0.5203 & 0.8231 & 0.4034 \\
\hline SOC1 & 0.4790 & 0.3070 & 0.4736 & 0.4188 & 0.4441 & 0.9428 \\
\hline SOC2 & 0.4707 & 0.3256 & 0.5250 & 0.4448 & 0.4516 & 0.9543 \\
\hline SOC3 & 0.4714 & 0.3261 & 0.4983 & 0.3716 & 0.4167 & 0.9387 \\
\hline
\end{tabular}

Table 2: Discriminant validity - Cross loading

\subsection{Structural Model}

The next step is to evaluate the structural model by looking at the effect size and $R$ square. The effect size value has several

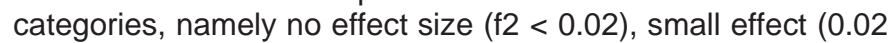
f2 $<0.15)$, medium effect $(0.15 \mathrm{f} 2<0.35)$, and large effect (f2 0.35) (Hair et al., 2019). Based on Table 3 shows the value of the effect size (f2) of each variable. The constructs of affect regulation, perceived safety and sociability have a small effect size. Meanwhile, construct disease denial, and fair price have no effect size. Then the next step is to see the value of $R$ square (R2). Table 4 shows the $R$ square adjusted value of 0.3345 . it means that there is a joint influence between the Affect regulation (AR), Disease Denial (DD) constructs, Fair Price (FP), 


\section{GENERAL MANAGEMENT}

Perceived Safety (PS) and Sociability (SOC) on the intention to visit a restaurant by $33.45 \%$.

\begin{tabular}{|l|l|l|}
\hline & Intention to Visit (IV) & Effect size \\
\hline Disease Denial (DD) & 0.0000 & No effect \\
\hline Perceived Safety (PS) & 0.0765 & Small \\
\hline Fair Price (FP) & 0.0024 & No effect \\
\hline Sociability (SOC) & 0.0277 & Small \\
\hline Affect regulation (AR) & 0.0308 & Small \\
\hline
\end{tabular}

Table 3: effect size

\begin{tabular}{|l|l|l|}
\hline & R Square & R Square Adjusted \\
\hline Intention to Visit (IV) & 0.3597 & 0.3345 \\
\hline
\end{tabular}

Table 4: $R$ Square

\subsection{Hypothesis testing}

This section discusses the results of statistical hypothesis testing. Table 6 below shows the results of smart pls regarding the relationship between variables and the influence between constructs.

\begin{tabular}{|l|l|l|l|l|}
\hline & $\begin{array}{l}\text { Original } \\
\text { Sample (O) }\end{array}$ & $\begin{array}{l}\text { T Statistics } \\
(\mid \mathbf{O} / \text { STDEV } \mid)\end{array}$ & P Values & Decision (10\%) \\
\hline Disease Denial (DD) -> Intention to Visit (IV) & 0.0025 & 0.0305 & 0.4878 & Rejected \\
\hline Perceived Safety (PS) -> Intention to Visit (IV) & 0.3210 & 2.8467 & 0.0023 & Accepted \\
\hline Fair Price (FP) -> Intention to Visit (IV) & 0.0576 & 0.5455 & 0.2928 & Rejected \\
\hline Sociability (SOC) -> Intention to Visit (IV) & 0.1651 & 1.4938 & 0.0679 & Accepted \\
\hline Affect regulation (AR) -> Intention to Visit (IV) & 0.1847 & 1.6756 & 0.0472 & Accepted \\
\hline
\end{tabular}

Table 5: Hypothesis testing

Based on table 6 above, there are 3 accepted hypotheses and 2 rejected hypotheses. 3 hypotheses that have a significant impact are affect regulation $(p$-value $=0.0472<0.1)$, perceived safety $(p$-value $=0.0023<0.1)$ and sociability $(p$-value $=0.0679$ $<0.1$ ). while the 2 hypotheses that did not have a significant impact on the intent to visit the restaurant were disease denial $(p$-value $=0.4878>0.1)$ and Fair Price $(p$-value $=0.4878>0.1)$.

Table 6 can also show the magnitude of the influence between constructs. For example, the Affect regulation (AR) and Intention to Visit (IV) constructs have an effect of 0.1847 or $18.47 \%$. while the constructs of Perceived Safety (PS) and Intention to Visit (IV) have an effect of 0.3210 or $32.1 \%$. Then the construct Sociability (SOC) and Intention to Visit (IV) have a significant effect of 0.1651 or $16.51 \%$. while the disease denial and fair price variables only had a non-significant impact on intention to visit, namely only 0.0025 or $0.25 \%$ and 0.0576 or $5.76 \%$.

\section{Discussion}

Based on the results of a survey that has been conducted from this research, it is known from the five factors tested; there are three factors that have a significant positive influence on a person's intention to visit a restaurant during the COVID-19 pandemic. Data processing shows that perceived safety has a significant impact on intention to visit restaurants where the COVID-19 pandemic is occurring. This means that if someone has a good perception of security towards a restaurant, that person will tend to visit the restaurant. The results of this study support previous research by Ozdemir et al. (2020) which explains that a good perception of the product causes the positive association with a brand. Besides, Kitz et al. (2020) also explained is that perceived safety will increase consumers' intention to visit restaurants during a pandemic. This perceived safety is seen from the health of the available food and from other sensory perspectives, for example, the odor that appears and the visible cleanliness (Bai et al., 2019). It is known from the survey results that the perceived safety factor is the most influential factor on a person's intention to visit a restaurant, which is $32.1 \%$.

The next factor that has a significant positive impact on a person's intention to visit a restaurant is sociability. From the results of this research, it is known that sociability has a significant positive impact on a person's intention to visit a restaurant during the pandemic. This means that the social environment's perception can increase a person's intention to visit a restaurant. This study supports the previous research by Dedeoğlu \& Boğan (2021), which explains that in a person consuming food, one of them is influenced by social influences. The pandemic condition gives limitations to social life because a person becomes less and less in socializing directly. This encourages when someone can visit a restaurant with friends or other people, it becomes an activity that is coveted and awaited. Furthermore, the third factor known to have a significant positive impact on a person's intention to visit a restaurant is affect regulation. Survey data shows that affect regulation has a significant positive impact on a person's intention to visit a restaurant. The results of this study are in line with the results of previous studies that stated that people who have a perception that food will influence the release of negative emotions tend to encourage them to visit restaurants (Dedeoğlu \& Boğan, 2021).

In addition to the three previous factors, there were two other factors that were tested in this study. The two factors are Disease denial and fair price. Both of these factors show that they do not significantly positively impact a person's intention to 
visit a restaurant. This means that if someone has a denial perception of the COVID-19 pandemic, they tend not to encourage that person to visit a restaurant. Furthermore, for fair price, if a person has a sensitivity to the prices offered by restaurant service providers, it turns out that this does not encourage that person to be willing to visit the restaurant. The results of this study for both factors, namely disease denial and fair price, are not in line with previous research by (Hakim et al., 2021). However, the results of this study encourage previous research by Asioli et al., (2017), which explains that consumer buying behaviour is based on the attributes of these goods or services. Thus, the existence of a person's disease denial of the covid pandemic does not then encourage someone's intention to visit a restaurant.

\section{Conclusion and Implication}

This study explains that three factors significantly affect a person's intention to visit a restaurant. The three factors are perceived safety, sociability and affect regulation. Perceived safety is the most influential factor for someone to have the intention to visit a restaurant. This certainly needs to be a concern for service providers in the restaurant sector, where their good name or positive association with a restaurant is the most influential component to encourage someone to have the intention to visit the restaurant. The next factor that can also be considered for service providers is the affect regulation factor. This factor illustrates that if someone feels happy to eat, then that person tends to be encouraged to have the intention of visiting a restaurant. Affect regulation affects a person's intention to visit a restaurant as much as 18.47. The next factor that can encourage someone to have the intention to visit a restaurant is sociability. This factor has a positive impact on a person's intention to visit a restaurant by $16.51 \%$. These three factors can be a reference for service providers regarding what strategies can effectively influence a person's intention to visit a restaurant during this COVID-19 pandemic. Service providers can focus more on developing the restaurant's good name to create a person's positive association with the restaurant. In addition, another strategy that can also be developed is regarding restaurant offers that are supportive of someone being able to visit a restaurant in groups as it is known that sociability has a significant positive impact on a person's intention to visit a restaurant. Furthermore, the affect regulation factor, which is proven to significantly positively affect a person's intention to visit a restaurant, can also be a reference for service providers in making marketing strategies to increase a person's intention to visit a restaurant.

\section{Limitation and Further Research Directions}

One of the limitations in this study is related to the research sample, which is only limited to the province of DKI Jakarta. Although this province is the country's capital city, expanding the sample to other provinces and comparing it with other provinces can produce more in-depth and comprehensive research results. Another limitation in this study is the limitations of the dimensions studied. The survey results show no factors that significantly influence a person's intention to visit a restaurant by $50 \%$ and above. This means that the possibility of a greater factor in influencing a person's intention to visit a restaurant needs to be explored further. In future research, factors such as welfare and other motivations can be added as variables to be studied in determining factors that can affect a person's intention to visit a restaurant. Further research can also add control variables such as age, financial condition, health condition.
From several control variables, it is expected to be able to provide more comprehensive results.

\section{References}

[1] Asioli, D., Varela, P., Hersleth, M., Almli, V. L., Olsen, N. V., \& Næs, T. (2017). A discussion of recent methodologies for combining sensory and extrinsic product properties in consumer studies. Food Quality and Preference, 56, 266-273. doi:10.1016/j.foodqual.2016.03.015

[2] Bai, L., Wang, M., Yang, Y., \& Gong, S. (2019). Food safety in restaurants: The consumer perspective. International Journal of Hospitality Management, 77, 139-146. doi:10.1016/j.ijhm.2018.06.023

[3] Berry, L. L. (2000). Cultivating Service Brand Equity. Journal of the Academy of Marketing Science, 28(1), 128-137. doi:10.1177/0092070300281012

[4] Costa, N. R. (2020). As medidas de enfrentamento `a pandemia da Covid-19 no Brasil na percepç̃ao da populaç̃ao atuante nas mídias sociais. Centro de Estudos Estrat'egicos Da Fiocruz.

[5] Dawes, J. (2008). Do Data Characteristics Change According to the Number of Scale Points Used? An Experiment Using 5Point, 7-Point and 10-Point Scales. International Journal of $\begin{array}{lll}\text { Market } & \text { Research, }\end{array}$ doi:10.1177/147078530805000106

[6] Dedeoğlu, B. B., \& Boğan, E. (2021). The motivations of visiting upscale restaurants during the COVID-19 pandemic: The role of risk perception and trust in government. International Journal of Hospitality Management, 95, 102905. doi:10.1016/j.ijhm.2021.102905

[7] Denial. (2020). In Oxford Dictionary. https://www.oxfordlearnersdictionaries.com/defini\%0Ation/engl ish/denial

[8] Hair, J. F., Risher, J. J., Sarstedt, M., \& Ringle, C. M. (2019). When to use and how to report the results of PLS-SEM. European Business Review, 31(1), 2-24. doi:10.1108/ebr-112018-0203

[9] Hakim, M. P., Zanetta, L. D. A., \& da Cunha, D. T. (2021). Should I stay, or should I go? Consumers' perceived risk and intention to visit restaurants during the COVID-19 pandemic in Brazil. Food Research International, 141(December 2020), 110152. https://doi.org/10.1016/j.foodres.2021.110152

[10] Hakim, M. P., Zanetta, L. D. A., de Oliveira, J. M., \& da Cunha, D. T. (2020). The mandatory labeling of genetically modified foods in Brazil: Consumer's knowledge, trust, and risk perception. Food Research International, 132(January), 109053. https://doi.org/10.1016/j.foodres.2020.109053

[11] Keni, K., \& Wilson, N. (2021). The Role of Consumers' Perceived Risk and Sales Promotion Towards Consumers' Intention to Visit in the Fast-Food Restaurant Sector During the Current COVID-19 Pandemic. Proceedings of the Ninth International Conference on Entrepreneurship and Business Management (ICEBM 2020). doi:10.2991/aebmr.k.210507.002

[12] Kitz, R., Charlebois, S., Walker, T., \& Music, J. (2020). Plastic Food Packaging: Before and After COVID. Report. https://www.dal.ca/sites/agri-food/\%0Aresearch/plastic-foodpackaging-before-and-after-covid-19.html\%3E.\%0AKoc, E. (2013). Inversionary and Liminoidal Consumption: Gluttony on

[13] Madeira, A., Palrão, T., \& Mendes, A. S. (2020). The Impact of Pandemic Crisis on the Restaurant Business. Sustainability, 13(1), 40. doi:10.3390/su13010040

[14] OpenTable. (2020). The state of the restaurant industry. OpenTable Inc. https://www.opentable.com/state-of-industry

[15] Ozdemir, S., Zhang, S. J., Gupta, S., \& Bebek, G. (2020). The effects of trust and peer influence on corporate brandConsumer relationships and consumer loyalty. Journal of Business Research, 117(February), 791-805. https://doi.org/10.1016/j.jbusres.2020.02.027

[16] Renner, B., Sproesser, G., Strohbach, S., \& Schupp, H. T. 


\section{GENERAL MANAGEMENT}

(2012). Why we eat what we eat. The Eating Motivation Survey
(TEMS).
Appetite,
$59(1)$
117-128.

doi:10.1016/j.appet.2012.04.004

[17] Rezaei, S. (2015). Segmenting consumer decision-making styles (CDMS) toward marketing practice: A partial least squares (PLS) path modeling approach. Journal of Retailing and Consumer Services, 22, 1-15. doi:10.1016/j.jretconser.2014.09.001

[18] Torales, J., O'Higgins, M., Castaldelli-Maia, J. M., \& Ventriglio, A. (2020). The outbreak of COVID-19 coronavirus and its impact on global mental health. International Journal of Social Psychiatry, 66(4), 317-320. doi:10.1177/0020764020915212

[19] Wheeler, A. (2017). Designing Brand Identity: An Essential Guide For The Entire Branding Team.

[20] Yost, E., \& Cheng, Y. (2021). Customers' risk perception and dine-out motivation during a pandemic: Insight for the restaurant industry. International Journal of Hospitality Management, 95, 102889. doi:10.1016/j.ijhm.2021.102889 